\title{
Chronic kidney disease in children: Assessment of oral health status
}

\section{Przewlekła niewydolność nerek u dzieci - ocena stanu zdrowia jamy ustnej}

\author{
Claudio Andaloro ${ }^{1, A-F}$, Concetto Sessa ${ }^{2, B, C}$, Nicolò Bua ${ }^{3, B, C}$, Ignazio La Mantia ${ }^{4, A-C, E, F}$ \\ ${ }^{1}$ ENT Unit, Santa Marta e Santa Venera Hospital, Acireale, Italy \\ ${ }^{2}$ Nephrology and Dialysis Center "Tike", Syracuse, Italy \\ ${ }^{3}$ Dental Unit, Department of Medical Surgery Specialities, University of Catania, Italy \\ ${ }^{4}$ Department of Medical Sciences, Surgical and Advanced Technologies, University of Catania, Italy \\ A - research concept and design; $\mathrm{B}$ - collection and/or assembly of data; $\mathrm{C}$ - data analysis and interpretation; \\ $D$ - writing the article; $E$ - critical revision of the article; $F$ - final approval of the article
}

\section{Address for correspondence}

Claudio Andaloro

E-mail: cla.anda@gmail.com

Funding sources

None declared

Conflict of interest

None declared

Received on November 20, 2017

Reviewed on December 19, 2017

Accepted on January 3, 2018

\begin{abstract}
Background. Oral disease may be more prevalent in people with chronic kidney disease (CKD) due to the underlying pathology and its treatment. In children, it can elicit a wide spectrum of oral manifestations, including saliva changes, mucosal lesions, oral infection, gingivitis, and dental anomalies (mostly hypoplasia).

Objectives. The aim of the study was to determine the oral health status in a group of children with CKD and to compare with that from healthy controls.
\end{abstract}

Material and methods. A clinical cross-sectional study was conducted between June 2016 and September 2017 on 126 pediatric patients. Oral findings in a group of 65 children suffering from CKD were compared with a control group consisting of 61 individuals, free of any disease. We obtained an assessment of the oral health status by collecting carious, debris, calculus, gingival conditions, hypoplasia, and salivary flow rate data by using specific indexes. Medical and dental history was obtained for each subject.

Results. We found that children with CKD have a lower prevalence of caries for both permanent dentition $(p=0.019)$ and primary dentition $(p=0.008)$, while the prevalence of calculus, debris, gingivitis and enamel hypoplasia seems to be higher $(a l l p<0.005)$. A significantly reduced salivary flow rate was also noted in the CKD children, both in unstimulated $(p=0.037)$ and stimulated $(p=0.026)$ conditions.

Conclusions. CKD pediatric patients are more likely to present oral and dental changes than healthy children, so proper oral care and preventive measures should be taken to avoid potentially severe dental problems.

Key words: oral health, enamel hypoplasia, chronic kidney disease

Słowa kluczowe: stan zdrowia jamy ustnej, hipoplazja szkliwa, przewlekła niewydolnośćnerek

D0I

$10.17219 / \mathrm{dmp} / 81747$

Copyright

○ 2018 by Wroclaw Medical University

and Polish Dental Society

This is an article distributed under the terms of the

Creative Commons Attribution Non-Commercial License

(http://creativecommons.org/licenses/by-nc-nd/4.0/) 


\section{Introduction}

Various medical conditions can affect the oral health of patients. Patients affected by chronic kidney disease (CKD), a progressive and irreversible deterioration of nephrons, which causes a decline in the glomerular filtration rate, may present a wide spectrum of oral manifestations in the hard and soft tissues as a results of the disease itself or/and the side effects of its treatment. ${ }^{1,2}$ Many oral manifestations can be observed in the oral cavity, such as an ammonia-like smell, gingival enlargement secondary to drug therapy with cyclosporine and/or calcium channel blockers, enamel hypoplasia, dental calculus and dry mouth, uremic stomatitis, mucositis and glossitis, gingival inflammation due to plaque accumulation caused by poor oral hygiene, and a wide range of oral mucosal lesions, mainly white patches and/or ulceration such as lichenoid disease as a consequence of the associated drug therapy, like diuretics and beta-blockers, or oral hairy leukoplakia, observed with uremia. ${ }^{3-9}$

Singularly, the prevalence of dental caries in patients with CKD has been reported as being lower compared with healthy children, mostly due to the massive amount of urea in the saliva of nephropathic patients, which led to less caries with its neutralizing plaque formation capacity and antibacterial properties. ${ }^{10}$ As there are numbers of studies describing and helping to understand the orodental manifestation and relevant treatment for adult patients with this disease, there are relatively few systematic studies of oral health status including pediatric patients.

Moreover, according to some studies, nephropathic children seem to use more health care services than other children. ${ }^{11}$ Therefore, there is a need for more research regarding the oral health of special care children to improve their standard of life through a proper oral care treatment.

The aim of this study was to determine the oral health status by collecting carious, debris, calculus, gingival, hypoplasia scores, and salivary flow rate in a group of children with CKD, and to compare the findings with those collected from healthy control groups.

\section{Material and methods}

A clinical cross-sectional study was conducted between June 2016 and September 2017 in the Otolaryngology Unit of the Santa Marta e Santa Venera Hospital in Acireale, Italy, after the approval by the ethical committee of the Unità Operativa Complessa (UOC) Otorinolaringoiatria - ASP 3 CT. The study included children with a diagnosis of CKD, based on the definition that combined estimated glomerular filtration rate (eGFR) values $<60 \mathrm{~mL} / \mathrm{min} / 1.73 \mathrm{~m}^{2}$ and albuminuria $\geq 30 \mathrm{mg} / \mathrm{g}$, before they had dialysis treatment, referred to our unit by the Nephrology and Dialysis Center "Tike", Syracuse, Italy. ${ }^{12}$
In addition, we included a group of healthy control participants for comparison. Patients who fulfilled the following exclusion criteria were not included in the study: age higher than 18 years or lower than 4 years, noncooperative behavior, other systemic disorders, and dental treatment received earlier. Signed written informed consent was obtained from the parents or guardians of all the children participating in the study.

In each child, demographic information, medical and dental history, and oral hygiene habits (tooth brushing and flossing) were based on patients' medical files and parents' replies.

All participants underwent a standardized oral examination by a dentist trained in periodontology, according to the World Health Organization (WHO) criteria. ${ }^{13}$

Caries status was determined by the decayed missing and filled teeth (DMFT) index in the permanent dentition or the dmft index in the primary dentition (the sum of decayed, missing or filled permanent teeth). ${ }^{14}$

With regard to oral hygiene habits, we decided to use the Simplified Oral Hygiene Index (OHI-S) for assessing individual levels of the oral health status. The OHI-S values may range from 0 to 6 , and the index has 2 components, the Debris Index and the Calculus Index. Each of these indexes is based on numerical determinations representing the amount of the debris or calculus found on the tooth surfaces. Possible scores for the Debris Index or the Calculus Index ranged between 0 (no debris or calculus present) and 3 (debris or supragingival calculus covering more than $2 / 3$ of the tooth surface) ${ }^{15}$

The Modified Gingival Index (MGI), a non-invasive (no probing) method to rate normal gingival status (score 0 ), a very mild (score 1 ), mild (score 2 ), moderate (score 3 ), and severe (score 4) inflammation, was used to assess the gingival status. ${ }^{16}$

The presence and severity of enamel defects were classified according to the most severe hypoplasia found in any tooth. The findings were scored according to the following scale: 1 . no hypoplasia; 2 . horizontal white discoloration, no missing enamel; 3. horizontal yellow-brown discoloration, no missing enamel; 4. pitted; 5 . horizontal fissures; 6 . whole enamel stained; 7 . whole enamel hypoplastic; 8 . morphologic anomalies. ${ }^{17}$

Differences of stimulated and unstimulated salivary flow rates were assessed through a test described elsewhere. ${ }^{18}$

The results obtained in the present study were analyzed using the SPSS software v. 20.0 (SPSS Inc., Chicago, USA). Quantitative variables were presented as mean $\pm \mathrm{SD}$, whereas categorical variables as numbers and frequency. The Kolmogorov-Smirnov test was used to evaluate the distribution of variables. Fisher's exact test or the $X^{2}$ test were used to study the categorical variables between patients and control subjects. The 2-sided t-test or the Mann-Whitney $U$ test were used to study the quantitative numeric variables between the 2 groups. Statistical significance was set at $\mathrm{p}<0.05$. 


\section{Results}

The present clinical study comprised of 126 children, whose general characteristics are presented in Table 1 . The participants in each of the 2 groups were statistically similar in terms of age and gender, and different with regard to the oral hygiene habits. Indeed, in the CKD group, the prevalence of children brushing teeth twice a day or more and using dental floss is significantly lower than in the control group ( $\mathrm{p}=0.047$ and $\mathrm{p}=0.024$, respectively). The number of non-brushing children is much higher in the CKD group than in the control group $(\mathrm{p}=0.031)$ (Table 1$)$.

The analysis of the differences in oral variables values between the 2 groups (Table 2) indicated a significant difference both in DMFT index for permanent dentition $(\mathrm{p}=0.019)$ and dmft index for primary dentition $(\mathrm{p}=0.008)$, with lower scores in the CKD group. Moreover, the CKD group showed a significantly higher Debris Index, Calculus Index and OHI-S overall index compared to the control group ( $\mathrm{p}=0.036, \mathrm{p}=0.028$ and $\mathrm{p}=0.033$, respectively).
Regarding the gingival status, the CKD group showed a higher prevalence of severe gingival inflammation $(\mathrm{p}=0.018)$ and a lower prevalence of normal gums ( $\mathrm{p}=0.026)$ compared to the control group, as revealed by MGI values. The severity of enamel hypoplasia was significantly higher in the CDK group as compared to controls (3.57 \pm 0.51 vs $0.09 \pm 0.25 ; \mathrm{p}=0.002$ ).

A significantly reduced salivary flow rate was observed in the CKD children, both in unstimulated $(0.07 \pm 0.01$ vs $0.15 \pm 0.02 ; \mathrm{p}=0.037)$ and stimulated $(0.13 \pm 0.03$ vs 0.36 $\pm 0.11 ; \mathrm{p}=0.026)$ conditions (Table 2).

\section{Discussion}

The results showed that the CKD group had a higher proportion of caries-free children than healthy children, free of any disease; indeed, the prevalence of caries is significantly lower in the CKD group than in controls for both DMFT and dmft scores, though the 2 studies did

Table 1. Demographics and oral hygiene habits of the 2 study groups

\begin{tabular}{|c|c|c|c|c|}
\hline Characteristics & $\begin{array}{c}\text { CKD group } \\
n=65\end{array}$ & $\begin{array}{l}\text { Control group } \\
\qquad n=61\end{array}$ & $\begin{array}{l}\text { Overall } \\
n=126\end{array}$ & $p$-value \\
\hline $\begin{array}{l}\text { Age, in years } \\
\text { mean } \pm S D \\
\text { median } \\
\text { range }\end{array}$ & $\begin{array}{c}9.92 \pm 2.75 \\
9 \\
5-16\end{array}$ & $\begin{array}{c}9.34 \pm 2.43 \\
9 \\
5-15\end{array}$ & $\begin{array}{c}10.11 \pm 3.31 \\
9 \\
5-16\end{array}$ & $\begin{array}{l}0.756 \\
- \\
-\end{array}$ \\
\hline $\begin{array}{c}\text { Gender, n (\%) } \\
\text { male } \\
\text { female }\end{array}$ & $\begin{array}{l}35(53.8) \\
30(46.2)\end{array}$ & $\begin{array}{l}32(52.5) \\
29(47.5)\end{array}$ & $\begin{array}{l}67(53.2) \\
59(46.8)\end{array}$ & $\begin{array}{l}0.624 \\
-\end{array}$ \\
\hline $\begin{array}{l}\text { Oral hygiene habits, } \mathrm{n}(\%) \\
\text { toothbrushing } \\
\text { never } \\
\text { once a day } \\
\text { twice a day or more } \\
\text { dental floss use }\end{array}$ & $\begin{array}{l}25(38.5) \\
23(35.4) \\
17(26.2) \\
12(18.5)\end{array}$ & $\begin{array}{l}14(23.0) \\
24(39.3) \\
23(37.7) \\
22(36.1)\end{array}$ & $\begin{array}{l}39(31.0) \\
47(37.3) \\
40(31.7) \\
34(27.0)\end{array}$ & $\begin{array}{l}0.031^{*} \\
0.893 \\
0.047^{*} \\
0.024^{*}\end{array}$ \\
\hline
\end{tabular}

* Significant difference at $p<0.05$.

Table 2. Oral variables of the 2 study groups

\begin{tabular}{|c|c|c|c|c|}
\hline Characteristics & $\begin{array}{l}\text { CKD group } \\
n=65\end{array}$ & $\begin{array}{l}\text { Control group } \\
\qquad n=61\end{array}$ & $\begin{array}{l}\text { Overall } \\
n=126\end{array}$ & $p$-value \\
\hline DMFT index & $6.86 \pm 1.69$ & $10.69 \pm 1.81$ & $8.78 \pm 1.75$ & $0.019^{*}$ \\
\hline dmft index & $7.02 \pm 1.75$ & $12.11 \pm 2.03$ & $9.57 \pm 1.89$ & $0.008^{*}$ \\
\hline Debris index & $1.33 \pm 0.43$ & $0.56 \pm 0.29$ & $0.95 \pm 0.36$ & $0.036^{*}$ \\
\hline Calculus index & $1.52 \pm 0.52$ & $0.32 \pm 0.11$ & $0.92 \pm 0.32$ & $0.028^{*}$ \\
\hline $\mathrm{OHI}-\mathrm{S}$ & $2.85 \pm 0.95$ & $0.88 \pm 0.40$ & $1.87 \pm 0.68$ & $0.033^{*}$ \\
\hline $\begin{array}{l}\text { MGl, n (\%) } \\
\text { normal } \\
\text { very mild } \\
\text { mild } \\
\text { moderate } \\
\text { severe }\end{array}$ & $\begin{array}{l}11(16.9) \\
10(15.4) \\
13(20.0) \\
16(24.6) \\
15(23.1)\end{array}$ & $\begin{array}{c}20(32.8) \\
14(23.0) \\
11(18.0) \\
11(18.0) \\
5(8.2)\end{array}$ & $\begin{array}{l}31(24.6) \\
24(19.0) \\
24(19.0) \\
27(21.4) \\
20(15.9)\end{array}$ & $\begin{array}{l}0.026^{*} \\
0.044^{*} \\
0.687 \\
0.091^{*} \\
0.018^{*}\end{array}$ \\
\hline Hypoplasia & $3.57 \pm 0.51$ & $0.09 \pm 0.25$ & $1.83 \pm 0.38$ & $0.002^{*}$ \\
\hline Salivary flow rate unstimulated (mL/min) & $0.07 \pm 0.01$ & $0.15 \pm 0.02$ & $0.11 \pm 0.02$ & $0.037^{*}$ \\
\hline Salivary flow rate stimulated (mL/min) & $0.13 \pm 0.03$ & $0.36 \pm 0.11$ & $0.25 \pm 0.07$ & $0.026^{*}$ \\
\hline
\end{tabular}

* Significant difference at $p<0.05$. 
not show any statistically significant differences in caries prevalence between the 2 groups. ${ }^{5,19}$ Our results are in agreement with those reported by Nakhjavani et al. and Sobrado Marinho et al. ${ }^{20,21}$ This may be due to the presence of highly buffered and alkaline saliva due to the elevated urea and phosphate concentrations in patients with renal disease, despite poor oral hygiene, a carbohydrate-rich diet (necessary to reduce the renal workload), in addition to disease-related debilitation, hypoplastic enamel and low salivary flow rate, usually seen in these patients. ${ }^{22}$ In order to establish the Oral Hygiene Index in children with CKD, we collected the debris and calculus scores. Both scores were significantly greater in the CKD group compared to healthy individuals, in accordance with a study by Martins et al. ${ }^{5}$ Elevated salivary $\mathrm{pH}$, decreased salivary magnesium, and high levels of salivary urea and phosphorus, probably due to the decrease in the glomerular filtration rate and urinary excretion, lead to the precipitation of calcium-phosphorus and calcium oxalate, and, thus, dental calculus formation. ${ }^{23}$ The issue of gingival inflammation in CKD patients appears to be very controversial in the literature. Several reports suggest reduced gingivitis in these patients, caused by immunosuppression and uremia, associated with the renal disease that may alter the inflammatory response to bacterial plaques in the gingival tissue. ${ }^{10,22,24}$ Also, it was said that a decreased level of hemoglobin can lead to paleness and mask the inflammatory signs in the gingival. ${ }^{2}$

However, other reports indicate opposite results. ${ }^{25}$ In experimentally induced gingivitis in CKD patients, Kitsou et al. concluded that chronic uremia had no effect on the defense of periodontal tissues against microbial plaque. ${ }^{26}$

In our study, the gingival status showed a higher prevalence of severe gingival inflammation in patients with CKD (23.1\%) than in those from the control group (8.2\%) $(\mathrm{p}=0.018)$. The greater gingival scores in our study may be attributed to the higher plaque rate among CKD patients and the increased inflammation in the involved tissues due to the systemic conditions that change the local tissue homeostasis. ${ }^{27}$

Enamel hypoplasia is a well-known phenomenon in CKD patients. ${ }^{10}$ Accordingly, in the present study, enamel hypoplasia was significantly more extensive and more severe in patients with CKD than in the control group. Calcium reduction together with renal disease that occurs during the mineralization of dentition can result in developmental defects of enamel as shown in several studies. ${ }^{22,28}$ A putative reason for the finding of poor dental health is the lower stimulated salivary secretion rate observed in the CKD group when compared with the control group. This supports previous findings indicating that a decrease in salivary flow is an important risk factor for poor dental health in hemodialysis patients. ${ }^{5}$

However, the present study has some limitations and the results should be interpreted in the context of its design. There is no data about the patients' classification of CKD. The 5 different CDK stages may affect the oral health status of the study patients in various ways, so it could be useful to create a study with all CKD stages (I-V). An additional limitation of this study was that the participants in this analysis were already diagnosed with CKD and before progression to the dialysis treatment, so we do not know how our results would relate to the length of the disease or dialysis therapy. A study over a longer period, evaluating these factors, may address these issues.

Another limitation is that a number of indexes and scores have been developed for assessing individual levels of the oral health status, so different score methods can lead to different results.

\section{Conclusions}

Within the limitations of the study, our data suggests that CKD children are more likely to present oral and dental changes than healthy ones. Therefore, a better understanding of the systemic and oral abnormalities in those individuals may help clinicians obtain effective oral care and plan preventive routines according to individual needs.

\section{References}

1. Fogo A, Kon W. Pathophysiology of progressive chronic renal disease. In: Avner ED, Harmon WE, Niaudet P, eds. Textbook of Pediatric Nephrology. Philadelphia, PA: Lippincott Williams \& Wilkins; 2004:1267-1480.

2. De Rossi SS, Glick M. Dental considerations for the patient with renal disease receiving hemodialysis. J Am Dent Assoc. 1996;127:211-219.

3. Kho HS, Lee SW, Chung SC, Kim YK. Oral manifestations and salivary flow rate, $\mathrm{pH}$, and buffer capacity in patients with end-stage renal disease undergoing hemodialysis. Oral Surg Oral Med Oral Pathol Oral Radiol Endod. 1999;88:316-319.

4. Kennedy DS, Linden GJ. Resolution of gingival overgrowth following change from cyclosporin to tacrolimus therapy in a renal transplant patient. J Ir Dent Assoc. 1999;46:3-4.

5. Martins C, Siqueira WL, Guimaraes Primo LS. Oral and salivary flow characteristics of a group of Brazilian children and adolescents with chronic renal failure. Pediatr Nephrol. 2008;23:619-624.

6. Antoniades DZ, Markopoulos AK, Andreadis D, Balaskas I, Patrikalou E, Grekas D. Ulcerative uremic stomatitis associated with untreated chronic renal failure: Report of a case and review of the literature. Oral Surg Oral Med Oral Pathol Oral Radiol Endod. 2006;101:608-613.

7. Olivas-Escárcega V, Ruiz-Rodríguez MDS, Fonseca-Leal MDP, et al. Prevalence of oral candidiasis in chronic renal failure and renal transplant pediatric patients. J Clin Pediatr Dent. 2008;32:313-317.

8. Torrelo A, Soria C, Rocamora A, Moreno R, Ledo A. Lichen planuslike eruption with esophageal involvement as a result of cyanamide. J Am Acad Dermatol. 1990;23:1168-1169.

9. McCreary CE, Flint SR, McCartan BE, Shields JA, Mabruk M, Toner ME. Uremic stomatitis mimicking oral hairy leukoplakia: Report of a case. Oral Surg Oral Med Oral Pathol Oral Radiol Endod. 1997;83:350-353.

10. Nunn JH, Sharp J, Lambert HJ, Plant ND, Coulthard MG. Oral health in children with renal disease. Pediatr Nephrol. 2000;14:997-1001.

11. Stein REK, Silver EJ. Comparing different definitions of chronic conditions in a national data set. Ambul Pediatr. 2002;2:63-70.

12. Levey AS, de Jong PE, Coresh J, et al. The definition, classification, and prognosis of chronic kidney disease: A KDIGO Controversies Conference report. Kidney Int. 2011;80:17-28.

13. World Health Organization. Oral Health Surveys - Basic Methods. $4^{\text {th }}$ ed. Geneva: World Health Organization; 1997. 
14. World Health Organization. GLOBAL DATA on DENTAL CARIES PREVALENCE (DMFT) in CHILDREN AGED 12 YEARS. Global Oral Data Bank. Oral health country/area profile programme. Geneva: World Health Organization; 2000.

15. Greene JG, Vermillion JR. The simplified oral hygiene index. J Am Dent Assoc. 1964;68:7-13.

16. Lobene RR, Weatherford T, Ross NM, Lamm RA, Menaker LA A modified gingival index for use in clinical trials. Clin Prev Dent. 1986;8:3-6.

17. Davidovich E, Schwarz Z, Davidovitch M, Eidelman E, Bimstein E. Oral findings and periodontal status in children, adolescents and young adults suffering from renal failure. J Clin Periodontol. 2005;32:1076-1082.

18. Sánchez-Pérez L, Irigoyen-Camacho E, Sáenz-Martínez L, ZepedaZepeda M, Acosta-Gío E, Méndez-Ramírez I. Stability of unstimulated and stimulated whole saliva flow rates in children. Int J Paediatr Dent. 2016;26:346-350.

19. Ertudrul F, Elbek-Çubukçu Ç, Sabah E, Mir S. The oral health status of children undergoing hemodialysis treatment. Turk J Pediatr. 2003;45:108-113.

20. Nakhjavani YB, Bayramy A. The dental and oral status of children with chronic renal failure. J Indian Soc Pedod Prev Dent. 2007;25:7-9.

21. Sobrado Marinho JS, Tomás Carmona I, Loureiro A, Limeres Posse J, García Caballero L, Diz Dios P. Oral health status in patients with moderate-severe and terminal renal failure. Med Oral Patol Oral Cir Bucal. 2007;12:305-310.

22. Al Nowaiser A, Roberts GJ, Trompeter RS, Wilson M, Lucas VS Oral health in children with chronic renal failure. Pediatr Nephrol. 2003;18:39-45.

23. Davidovich E, Davidovits M, Peretz B, Shapira J, Aframian DJ. The correlation between dental calculus and disturbed mineral metabolism in paediatric patients with chronic kidney disease. Nephrol Dial Transplant. 2009;24:2439-2445.

24. Lucas VS, Roberts GJ. Oro-dental health in children with chronic renal failure and after renal transplantation: A clinical review. Pediatr Nephrol. 2005;20:1388-1394.

25. Naugle K, Darby ML, Bauman DB, Lineberger LT, Powers R. The oral health status of individuals on renal dialysis. Ann Periodontol. 1998;3:197-205.

26. Kitsou VK, Konstantinidis A, Siamopoulos KC. Chronic renal failure and periodontal disease. Ren Fail. 2000;22:307-318.

27. Gallardo JM, de Carmen Prado-Uribe M, Amato D, Paniagua R. Inflammation and oxidative stress markers by pentoxifylline treatment in rats with chronic renal failure and high sodium intake. Arch Med Res. 2007;38:34-38.

28. Andaloro C, Sati M, Grillo C, Grillo CM, La Mantia I. Relationship between sleeping difficulties and airway symptoms severity with the health-related quality of life in patients with GERD. Minerva Gastroenterol Dietol. 2017;63:307-312. 
